\title{
EFFECT OF USING CORN DISTILLERS DRIED GRAINS WITH SOLUBLE (DDGS) ON BROILER CHICKS PERFORMANCE
}

\author{
SAMAN ABDULMAJID RASHID; HERSH ABDULAZAL FARAJ; RAOUF HUSSEIN MAJEED; \\ ATA MUHAMMAD SALIH; KURDO UMED HAMA AZIZ and AZAD ABDULKARIM \\ MUHAMMAD
}

University of Sulaimani, Faculty of Agricultural Sciences, Animal Production Department.

Email: saman.rashid@univsul.edu.iq

Assiut University web-site: www.aun.edu.eg

\section{ABSTRACT}

Received at: 11/10/2015

Accepted: 30/10/2015
To evaluate the effect of utilization of corn distillers dried grains with soluble (DDGS) as partial alternative of soybean meal on broiler chicks performance, 96 chicks of ROSS 308 were used and they fed diets with 0, 15, 30 and $45 \%$ DDGS in grower and finisher diets (Control group, T2, T3 and T4, respectively) from 8 to 42 days of age. At the end of the experiment (42 days of age), body weight of the chickens in groups T2 and T3 were (2897.33g and $2967.67 \mathrm{~g}$, respectively) and they were significantly heavier $(\mathrm{P}<0.05)$ as comparison with chickens in control group (2537.33 g). Also, weight gain at 36-42 days of age, in groups T2, T3 and $\mathrm{T} 4$ (587.33g, 569.33g and 615.33, respectively) were significantly higher $(\mathrm{P}<0.05)$ than chickens in control group (444.00g). While, feed intake in T2 was (1250.00g) at the end of the experiment and significantly increased as compared to the control group which was $(956.33 \mathrm{~g})$. Although, feed conversion ratio at 42 day of age in $\mathrm{T} 1$ was $(2.16 \mathrm{~g})$ and it is higher in comparison with $\mathrm{T} 4$ which was $(1.90 \mathrm{~g})$. At the end of the experiment, carcass, breast and thigh weights, in the chickens of group T3 recorded significantly $(\mathrm{P}<0.05)$ high weight as compared with chickens in control group. While, there were no significant differences among the groups in wing weight and weight of other organs in this experiment. Protein percentage in breast meat at the end of the experiment in group T4 (23.93\%) were significantly higher $(\mathrm{P}<0.05)$ as compared with chickens in control group $(21.17 \%)$.

Key words: Corn distillers, (DDGS), Broiler chicks, Performance

\section{INTRODUCTION}

All nutrients of raw materials are more concentrated in DDGS except nitrogen free extracts, because they are fermented with alcohol. DDGS are mainly source of crude protein, the contents of fat, minerals and fiber are also increased in comparison with the raw material (Belyea et al., 2004, Foltyn et al., 2013). Corn DDGS generally contains approximately $27 \%$ crude protein, $10 \%$ fat, $0.8 \% \mathrm{P}$ and $0.7 \% \mathrm{~S}$ and suitable feed for both cattle and poultry (Leaflet, 2008). The amount and quality of DDGS are very variable depending mainly on raw material quality. DDGS has the same dry matter and energy content like corn and content of other nutrients ranged from 2.5 to 3 times higher than in corn. The risk of contamination by mycotoxin in "new generation" DDGS is very low, because the quality of raw material affects the yield of ethanol (Foltyn et al., 2013). There were three types of residual co-products produced from fermentation of grains with alcohol. These include Distillers Dried Grains (DDG), Distillers Dried Soluble (DDS) and Distillers Dried Grains with Soluble (DDGS). Wang et al. (2007a) found that (DDS) fraction is the richest source of vitamins, the lowest in fiber and the highest in fat, yielding approximately $91 \%$ digestible energy (DE) value of the corn. Moreover, Production of ethanol from $100 \mathrm{~kg}$ of corn using the dry-milling method produces approximately $34.4 \mathrm{~kg}$ of ethanol, $34.0 \mathrm{~kg}$ of carbon dioxide, and $31.6 \mathrm{~kg}$ of DDGS (RFA. 2005). Researchers have consistently observed positive performance and meat quality when DDGS is added to broiler diets. Day et al. (1973) showed that weight gain of broilers was increased when low 
levels of DDGS (2.5 and 5\%) were added to the diet compared to broilers fed the control diet. Waldroup et al. (1981) demonstrated that DDGS can be added to broiler diets at levels up to $25 \%$ to achieve good performance if dietary energy level is held constant. The objective of this experiment was to study the effect of replacing distillers dried grains with soluble (DDGS) for soybean meal at levels of $0,15,30$ and $45 \%$ with detecting their affects on broiler performance and meat quality.

\section{MATERIALS and METHODS}

A total number of 96 unsexed day old (Rose 308) broiler chicks were used in this experiment. At eightdays of age, chicks were divided equally on floor pens into 4 groups, each group contained 4 replicates of 6 chicks per each, according the proportion of SBM (soybean meal) and DDGS in the diets. DDGS were not used in the control group. DDGS were used at levels 15,30 and $45 \%$ in second, third and fourth groups (T2, T3 and T4).

Table 1: Level of Soybean and DDGS substitution in birds diets.

\begin{tabular}{ccc}
\hline \multirow{2}{*}{ Treatment } & \multicolumn{3}{c}{ days (8-42) } \\
\cline { 2 - 3 } & \% Soybean & \% DDGS \\
\hline $\mathrm{T} 1$ & 100 & 0 \\
\hline $\mathrm{T} 2$ & 85 & 15 \\
\hline $\mathrm{T} 3$ & 70 & 30 \\
\hline $\mathrm{T} 4$ & 55 & 45 \\
\hline
\end{tabular}

Table 2: Composition and chemical analysis of the starter diet (1-7 days of age).

\begin{tabular}{|c|c|}
\hline Feed Ingredients & $\%$ \\
\hline Yellow corn & 49 \\
\hline Soybean meal & 30 \\
\hline Protein concentrate & 3.56 \\
\hline Wheat & 12.5 \\
\hline $\mathrm{NaCl}$ & 0.30 \\
\hline Sun flower seed oil & 3 \\
\hline Vit. Min. Premix & 0.30 \\
\hline Limestone & 1.34 \\
\hline total & 100 \\
\hline
\end{tabular}

Chemical compositions

\begin{tabular}{ll}
\hline Crude protein $\%$ & 22.00 \\
\hline Metabolizable energy (calculated) & 3169 \\
\hline Calcium & 0.35 \\
\hline Lysine & 1.18 \\
\hline $\begin{array}{l}\text { Methionine } \\
\text { (calculated) }\end{array}$ & 0.58 \\
\hline
\end{tabular}


$\underline{\text { Assiut Vet. Med. J. Vol. } 61 \text { No. } 147 \text { October } 2015}$

Table 3: Composition and chemical analysis of the grower diet (8-21 days of age).

\begin{tabular}{lcccc}
\hline \multicolumn{1}{c}{ Feed Ingredients } & T1 & T2 & T3 & T4 \\
\hline Yellow corn & 49 & 42 & 38 & 38.3 \\
\hline DDGS & 0 & 4.5 & 9 & 16.2 \\
\hline Soybean meal & 30 & 25.2 & 21 & 19.5 \\
\hline Protein concentrate & 3.56 & 6 & 8.8 & 7.06 \\
\hline Wheat & 12.5 & 17.36 & 18.26 & 14 \\
\hline $\mathrm{NaCl}$ & 0.3 & 0.3 & 0.3 & 0.3 \\
\hline Sun flower seed oil & 3 & 3 & 3 & 3 \\
\hline Vit. Min. Premix & 0.30 & 0.30 & 0.30 & 0.30 \\
\hline Limestone & 1.34 & 1.34 & 1.34 & 1.34 \\
\hline Total & 100 & 100 & 100 & 100 \\
\hline & Chemical compositions & & \\
\hline Crude protein \% & 22.00 & 22.00 & 22.00 & 22.00 \\
\hline $\begin{array}{l}\text { Metabolizable energy } \\
\text { (calculated) }\end{array}$ & 3169 & 3112 & 3148 & 3127 \\
\hline Calcium & 0.35 & 0.6 & 0.92 & 1 \\
\hline Lysine & 1.18 & 1.3 & 1.44 & 1.58 \\
\hline $\begin{array}{l}\text { Methionine } \\
\text { (calculated) }\end{array}$ & 0.58 & 0.6 & 0.88 & 0.92 \\
\hline
\end{tabular}

The diets were formulated to have isoenergy and protein contents. In this experiment all chickens were fed the same commercial diet till $7^{\text {th }}$ day of age, at this day all chickens were weighted and divided into the four experimental groups. Diets were formulated to meet the requirements according to the National Research Council (NRC), (1994). The feed and water provide ad libitum during the experiment.

At the end of this experiment, all data were analyzed using XL Stat (XISTAT, 2004). The significant differences between the means of traits were determined using Duncan's multiple range tests (Duncan, 1955) under the probability $\mathrm{P}<0.05$.

The studied traits was weekly recorded (body weight and feed intake) while (body weight gain and feed conversion) were calculated. Carcass traits including breast, thigh, wing, liver, gizzard and heart weight were recorded. Chemical composition of breast and thigh (protein, lipid, moisture and ash) were estimated.

Table 4: Compositions and chemical analysis of the finisher diet (22-42 days of age).

\begin{tabular}{|c|c|c|c|c|}
\hline Feed Ingredients & T1 & $\mathbf{T 2}$ & T3 & T4 \\
\hline Yellow corn & 51 & 51 & 48 & 45 \\
\hline DDGS & 0 & 3.7 & 7.5 & 11.25 \\
\hline Soybean meal & 24.7 & 20.7 & 17.2 & 13.45 \\
\hline Protein concentrate & 3.36 & 5.66 & 8.36 & 10.36 \\
\hline Wheat & 16 & 14 & 14 & 15 \\
\hline $\mathrm{NaCl}$ & 0.30 & 0.30 & 0.30 & 0.30 \\
\hline Sun flower seed oil & 3 & 3 & 3 & 3 \\
\hline Vit. Min. Premix & 0.30 & 0.30 & 0.30 & 0.30 \\
\hline Limestone & 1.34 & 1.34 & 1.34 & 1.34 \\
\hline Total & 100 & 100 & 100 & 100 \\
\hline \multicolumn{5}{|c|}{ Chemical composition } \\
\hline Crude protein $\%$ & 20 & 20 & 20 & 20 \\
\hline $\begin{array}{l}\text { Metabolizable energy } \\
\text { (calculated) }\end{array}$ & 3226 & 3249 & 3257 & 3276 \\
\hline Calcium & 0.34 & 0.57 & 0.87 & 1.1 \\
\hline Lysine & 1.05 & 1.15 & 1.29 & 1.39 \\
\hline $\begin{array}{l}\text { Methionine } \\
\text { (calculated) }\end{array}$ & 0.57 & 0.68 & 0.83 & 0.95 \\
\hline
\end{tabular}




\section{RESULTS}

\subsection{Body weight:}

Table 5 shows results of weighing at weekly intervals from 8 to the 42 day of age. There was significant ( $P$ $<0.05)$ difference between $\mathrm{T} 2$ and control group in body weight. At 28 and 35 days of age there was significantly $(\mathrm{P}<0.05)$ increase in body weight of chickens in T2, T3 and T4 supplemented with DDGS in the diet compared with the control one. At the end of the experiment, chickens fed on diet supplemented with 15, 30 and 45\% DDGS had significant $(\mathrm{P}<0.05)$ higher body weight $(2897.33 \mathrm{~g}, 2967.67 \mathrm{~g}$ and $2802.00 \mathrm{~g}$, respectively) compared with control (2537.33g).

Table 5: Body weight development of broiler chicks during experimental period. (means \pm SE)

\begin{tabular}{|c|c|c|c|c|c|c|}
\hline \multirow[b]{2}{*}{ Treatments } & \multicolumn{6}{|c|}{ Age (days) } \\
\hline & 7 & 14 & 21 & 28 & 35 & 42 \\
\hline $\mathrm{T} 1$ (control) & $\begin{array}{c}203.33 \\
\pm 14.26^{\mathrm{b}}\end{array}$ & $\begin{array}{c}447.00 \\
\pm 18.25^{\mathrm{b}}\end{array}$ & $\begin{array}{l}1001.00 \\
\pm 20.60^{\mathrm{b}}\end{array}$ & $\begin{array}{l}1580.00 \\
\pm 30.55^{\mathrm{c}}\end{array}$ & $\begin{array}{l}2093.33 \\
\pm 29.06^{\mathrm{d}}\end{array}$ & $\begin{array}{l}2537.33 \\
\pm 32.79^{c}\end{array}$ \\
\hline $\mathrm{T} 2$ & $\begin{array}{c}195.67 \\
\pm 14.37^{\mathrm{ab}}\end{array}$ & $\begin{array}{c}547.00 \\
\pm 13.58^{\mathrm{a}}\end{array}$ & $\begin{array}{l}1079.33 \\
\pm 10.48^{\mathrm{a}}\end{array}$ & $\begin{array}{l}1750.00 \\
\pm 36.06^{\mathrm{ab}}\end{array}$ & $\begin{array}{l}2310.00 \\
\pm 20.00^{b}\end{array}$ & $\begin{array}{l}2897.33 \\
\pm 26.33^{\mathrm{a}}\end{array}$ \\
\hline $\mathrm{T} 3$ & $\begin{array}{c}198.67 \\
\pm 15.26^{\mathrm{b}}\end{array}$ & $\begin{array}{c}500.33 \\
\pm 14.77^{\mathrm{ab}}\end{array}$ & $\begin{array}{l}1072.67 \\
\pm 32.09^{\mathrm{ab}}\end{array}$ & $\begin{array}{l}1820.00 \\
\pm 21.94^{\mathrm{a}}\end{array}$ & $\begin{array}{c}2398.33 \\
\pm 8.84^{\mathrm{a}}\end{array}$ & $\begin{array}{l}2967.67 \\
\pm 23.54^{\mathrm{a}}\end{array}$ \\
\hline $\mathrm{T} 4$ & $\begin{array}{c}213.67 \\
\pm 15.23^{\mathrm{a}}\end{array}$ & $\begin{array}{c}550.33 \\
\pm 25.67^{\mathrm{a}}\end{array}$ & $\begin{array}{l}1012.67 \\
\pm 15.32^{\mathrm{ab}}\end{array}$ & $\begin{array}{l}1695.33 \\
\pm 37.67^{b}\end{array}$ & $\begin{array}{l}2186.67 \\
\pm 28.48^{\mathrm{c}}\end{array}$ & $\begin{array}{l}2802.00 \\
\pm 30.37^{b}\end{array}$ \\
\hline
\end{tabular}

*: Means with different superscript within factor or factors combination differ significantly $(\mathrm{p}<0.05)$.

\subsection{Weight gain:}

The effect of (DDGS) as partial alternative of soybean meal on body weight gain (BWG) are shown in Table 6. The results showed that there was significant effect $(\mathrm{P}<0.01)$ on $(\mathrm{BWG})$. At the beginning of the experiment at 7 days of age the highest value of BWG was recorded by birds fed $15 \%$ DDGS (351.33g) compared to the control group $(243.67 \mathrm{~g})$, while at 21 days of age there was in significant difference among the groups T2 and T3 with control. However, at 28 days of age, T3 and T4 significantly higher in weight gain as comparison with control, thereafter there was no significant difference between the groups at 35 day of age.

At the end of the experiment (42 day of age), BWG of chickens in groups T2, T3 and T4 $(2701.66 \mathrm{~g}$, $2769.00 \mathrm{~g}$ and $2588.39 \mathrm{~g})$ respectively were significantly increased $(\mathrm{P}<0.05)$ in comparison with chickens in control group (2334.0 g).

Table 6: Effect of utilization (DDGS) as partial alternative of soybean meal on body weight gain (g) of broiler chicks performance. (Means \pm SE)

\begin{tabular}{|c|c|c|c|c|c|c|}
\hline \multirow{2}{*}{ Treatments } & \multicolumn{6}{|c|}{ Age (days) } \\
\hline & 8-14 & $15-21$ & $22-28$ & $29-35$ & $36-42$ & $8-42$ \\
\hline T1(control) & $\begin{array}{c}243.67 \\
\pm 11.20^{c}\end{array}$ & $\begin{array}{c}554.00 \\
\pm 23.97^{\mathrm{a}}\end{array}$ & $\begin{array}{c}579.00 \\
\pm 10.54^{b}\end{array}$ & $\begin{array}{c}513.33 \\
\pm 43.72^{\mathrm{a}}\end{array}$ & $\begin{array}{c}444.00 \\
\pm 15.63^{b}\end{array}$ & $\begin{array}{c}2334.00 \\
\pm 174.88^{\mathrm{c}}\end{array}$ \\
\hline $\mathrm{T} 2$ & $\begin{array}{l}351.33 \\
\pm 9.40^{\mathrm{a}}\end{array}$ & $\begin{array}{l}532.33 \\
\pm 8.25^{\mathrm{a}}\end{array}$ & $\begin{array}{c}670.67 \\
\pm 46.51^{\mathrm{ab}}\end{array}$ & $\begin{array}{c}560.00 \\
\pm 26.46^{\mathrm{a}}\end{array}$ & $\begin{array}{c}587.33 \\
\pm 31.94^{\mathrm{a}}\end{array}$ & $\begin{array}{c}2701.66 \\
\pm 186.04^{\mathrm{a}}\end{array}$ \\
\hline $\mathrm{T} 3$ & $\begin{array}{c}301.00 \\
\pm 16.09^{b}\end{array}$ & $\begin{array}{c}572.33 \\
\pm 19.22^{\mathrm{a}}\end{array}$ & $\begin{array}{c}747.33 \\
\pm 21.74^{\mathrm{a}}\end{array}$ & $\begin{array}{c}578.33 \\
\pm 13.86^{\mathrm{a}}\end{array}$ & $\begin{array}{c}569.33 \\
\pm 21.26^{\mathrm{a}}\end{array}$ & $\begin{array}{l}2769.00 \\
\pm 86.96^{\mathrm{a}}\end{array}$ \\
\hline $\mathrm{T} 4$ & $\begin{array}{c}336.00 \\
\pm 17.67^{\mathrm{ab}}\end{array}$ & $\begin{array}{c}462.33 \\
\pm 10.49^{b}\end{array}$ & $\begin{array}{c}682.67 \\
\pm 23.14^{\mathrm{a}}\end{array}$ & $\begin{array}{c}491.33 \\
\pm 53.47^{\mathrm{a}}\end{array}$ & $\begin{array}{c}615.33 \\
\pm 20.42^{\mathrm{a}}\end{array}$ & $\begin{array}{c}2588.33 \\
\pm 213.88^{b}\end{array}$ \\
\hline
\end{tabular}

*: Means with different superscript within factor or factors combination differ significantly $(\mathrm{p}<0.05)$. 


\subsection{Feed intake:}

Results of the feed intake (FI) are shown in Table 7. At the beginning of the experiment, at 8-14 days of age, T1, T2 and T3 had significantly increased in FI as compared with control T1. Adversely, at 15-21 days of age with increasing the percentage of DDGS levels, feed consumption was decreased. While in the following week the differences among groups were not significant.

Table 7: Effect of utilization (DDGS) as partial alternative of soybean meal on feed intake (g) of broiler chicks performance. (Means \pm SE)

\begin{tabular}{|c|c|c|c|c|c|c|}
\hline \multirow{2}{*}{ Treatments } & \multicolumn{6}{|c|}{ Age (days) } \\
\hline & $8-14$ & $15-21$ & $22-28$ & $29-35$ & $36-42$ & $8-42$ \\
\hline \multirow{2}{*}{ T1(control) } & 313.00 & 665.00 & 832.67 & 862.33 & 956.33 & 3629.33 \\
\hline & $\pm 22.19^{\mathrm{b}}$ & $\pm 13.28^{\mathrm{a}}$ & $\pm 34.71^{\mathrm{a}}$ & $\pm 52.33^{\mathrm{c}}$ & $\pm 28.82^{c}$ & $\pm 116.72^{\mathrm{c}}$ \\
\hline \multirow{2}{*}{$\mathrm{T} 2$} & 392.00 & 639.67 & 869.00 & 994.67 & 1250.00 & 4145.34 \\
\hline & $\pm 11.24^{\mathrm{a}}$ & $\pm 24.18^{\mathrm{ab}}$ & $\pm 5.57^{\mathrm{a}}$ & $\pm 30.43^{\mathrm{b}}$ & $\pm 17.95^{\mathrm{a}}$ & $\pm 134.18^{a}$ \\
\hline \multirow{2}{*}{$\mathrm{T} 3$} & 405.67 & 634.33 & 848.67 & 1132.00 & 1128.00 & 4148.67 \\
\hline & $\pm 5.67^{\mathrm{a}}$ & $\pm 9.82^{\mathrm{ab}}$ & $\pm 16.27^{\mathrm{a}}$ & $\pm 18.77^{\mathrm{a}}$ & $\pm 44.51^{\mathrm{a}}$ & $\pm 141.67^{\mathrm{a}}$ \\
\hline \multirow{2}{*}{$\mathrm{T} 4$} & 399.00 & 606.00 & $804.00 \pm$ & 862.67 & 1164.33 & 3836.00 \\
\hline & $\pm 13.80^{\mathrm{a}}$ & $\pm 6.81^{\mathrm{b}}$ & $20.00^{\mathrm{a}}$ & $\pm 45.02^{\mathrm{c}}$ & $\pm 24.21^{\mathrm{ab}}$ & $\pm 122.83^{\mathrm{a}}$ \\
\hline
\end{tabular}

*: Means with different superscript within factor or factors combination differ significantly $(\mathrm{p}<0.05)$.

Although, in the 22-35 day of age, T3 and T2 $(1132.00 \mathrm{~g}, \quad 994.67 \mathrm{~g}$, respectively) FI had significantly increased as compared to control $(862.33 \mathrm{~g})$. Moreover, at the end of the attempt (36-42 days of age), T2, T3 and T4 (1250.00g, $1128.00 \mathrm{~g}$ and $1164.33 \mathrm{~g}$, respectively) recorded significantly higher feed intake than control (956.33g).

\subsection{Feed conversion ratio}

The results of feed conversion ratio (FCR) is shown in Table 8. At the beginning of attempts at 14 days, there were not significant differences among T1, T3 and $\mathrm{T} 4$ in feed conversion ratio. At 21 days of age the differences between $\mathrm{T} 1, \mathrm{~T} 2$ and $\mathrm{T} 4$ were not significant.

Table 8: Effect of utilization (DDGS) as partial alternative of soybean meal on feed conversion ratio (FCR) of broiler chicks performance. (Means \pm SE)

\begin{tabular}{|c|c|c|c|c|c|c|}
\hline \multirow{2}{*}{ Treatments } & \multicolumn{6}{|c|}{ Age (days) } \\
\hline & $8-14$ & $15-21$ & $22-28$ & $29-35$ & $36-42$ & $8-42$ \\
\hline $\mathrm{T} 1$ (control) & $1.29 \pm 0.09^{\mathrm{ab}}$ & $1.20 \pm 0.03^{\mathrm{ab}}$ & $1.44 \pm 0.03^{\mathrm{a}}$ & $1.69 \pm 0.05^{\mathrm{b}}$ & $2.16 \pm 0.05^{\mathrm{a}}$ & $1.56 \pm 0.06^{\mathrm{a}}$ \\
\hline $\mathrm{T} 2$ & $1.12 \pm 0.05^{\mathrm{b}}$ & $1.20 \pm 0.06^{\mathrm{ab}}$ & $1.31 \pm 0.09^{\mathrm{ab}}$ & $1.78 \pm 0.07^{\mathrm{ab}}$ & $2.14 \pm 0.11^{\mathrm{ab}}$ & $1.53 \pm 0.05^{\mathrm{ab}}$ \\
\hline $\mathrm{T} 3$ & $1.35 \pm 0.06^{\mathrm{a}}$ & $1.11 \pm 0.04^{\mathrm{b}}$ & $1.14 \pm 0.05^{\mathrm{b}}$ & $1.96 \pm 0.05^{\mathrm{a}}$ & $1.98 \pm 0.00^{\mathrm{ab}}$ & $1.50 \pm 0.04^{\mathrm{ab}}$ \\
\hline $\mathrm{T} 4$ & $1.19 \pm 0.06^{\mathrm{ab}}$ & $1.31 \pm 0.02^{\mathrm{a}}$ & $1.18 \pm 0.03^{\mathrm{b}}$ & $1.78 \pm 0.09^{\mathrm{ab}}$ & $1.90 \pm 0.09^{\mathrm{b}}$ & $1.48 \pm 0.12^{b}$ \\
\hline
\end{tabular}

*: Means with different superscript within factor or factors combination differ significantly $(\mathrm{p}<0.05)$. 


\subsection{Carcass and carcass traits weight:}

The effects of feeding different levels of DDGS on carcass traits including (carcass, breast, thigh and wing) weights are presented in Table 9. Carcass weight in the T3 (1893.33g) is higher than all of supplemented DDGS groups and control group $(1590.00 \mathrm{~g})$.

Table 9: Effect of utilization (DDGS) as partial alternative of soybean meal on Carcass, breast, thigh and wing weight $(\mathrm{g})$ of broiler chicks performance. (Means \pm SE)

\begin{tabular}{ccccc}
\hline \multirow{2}{*}{ Treatments } & \multicolumn{4}{c}{ Carcass weight and Carcass cuts weights (kg) } \\
\cline { 2 - 5 } & Carcass weight & Breast weight & Thigh weight & Wing weight \\
\hline T1(control) & $1590.00 \pm 37.86^{\mathrm{b}}$ & $546.67 \pm 13.33^{\mathrm{b}}$ & $453.33 \pm 17.64^{\mathrm{b}}$ & $213.33 \pm 6.67^{\mathrm{ab}}$ \\
\hline T2 & $1626.67 \pm 33.33^{\mathrm{b}}$ & $600.00 \pm 11.55^{\mathrm{ab}}$ & $480.00 \pm 30.55^{\mathrm{b}}$ & $193.33 \pm 6.67^{\mathrm{ab}}$ \\
\hline T3 & $1893.33 \pm 58.12^{\mathrm{a}}$ & $673.33 \pm 43.72^{\mathrm{a}}$ & $593.33 \pm 29.06^{\mathrm{a}}$ & $240.00 \pm 20.00^{\mathrm{a}}$ \\
\hline $\mathrm{T} 4$ & $1593.33 \pm 63.60^{\mathrm{b}}$ & $533.33 \pm 40.55^{\mathrm{b}}$ & $426.67 \pm 29.06^{\mathrm{b}}$ & $186.67 \pm 17.64^{\mathrm{b}}$ \\
\hline
\end{tabular}

*: Means with different superscript within factor or factors combination differ significantly $(\mathrm{p}<0.05)$.

1.6 Liver, heart and gizzard weights:

Results presented in Table 10 clarified the effect of DDGS levels on liver, heart and gizzard weights. Results showed that there were no significant differences among the groups in terms of liver weight, gizzard and heart weight.

Table 10: Effect of utilization (DDGS) as partial alternative of soybean meal on liver, gizzard and heart weight (g) of broiler chicks performance. (Means \pm SE)

\begin{tabular}{cccc}
\hline \multirow{2}{*}{ Treatments } & \multicolumn{3}{l}{ Organs weight $(\mathrm{g})$} \\
\cline { 2 - 4 } & Liver weight & Gizzard weight & Heart weight \\
\hline $\mathrm{T} 1$ (control) & $53.33 \pm 6.67^{\mathrm{a}}$ & $26.67 \pm 6.67^{\mathrm{a}}$ & $20.00 \pm 0.00^{\mathrm{a}}$ \\
\hline $\mathrm{T} 2$ & $53.33 \pm 6.67^{\mathrm{a}}$ & $33.33 \pm 6.67^{\mathrm{a}}$ & $20.00 \pm 0.00^{\mathrm{a}}$ \\
\hline $\mathrm{T} 3$ & $60.00 \pm 0.00^{\mathrm{a}}$ & $33.33 \pm 6.67^{\mathrm{a}}$ & $20.00 \pm 0.00^{\mathrm{a}}$ \\
\hline $\mathrm{T} 4$ & $43.33 \pm 8.82^{\mathrm{a}}$ & $26.67 \pm 6.67^{\mathrm{a}}$ & $16.67 \pm 3.33^{\mathrm{a}}$ \\
\hline
\end{tabular}

*: Means with different superscript within factor or factors combination differ significantly $(\mathrm{p}<0.05)$.

2 Chemical composition of broiler chicken meat: 2.1 Estimation of the protein, lipid, moisture and ash in breast meat:

The effect of DDGS levels on protein, lipid, moisture and ash percentages in breast meat are shown in Table 11. In T4 (23.93\%) contained higher percentage of protein in breast meat $(\mathrm{P}<0.05)$ in comparison with T1 (21.17\%), may be due to higher protein percentage in DDGS. While, differences between treatment groups in percentage of lipid in breast meat were not significant, (Schilling et al., 2010) reported that there were no differences among the groups fed with $0,6,12,18$ and 24\% DDGS on $\mathrm{CP}$ and $\mathrm{CF}$ in broilers breast and thigh meat. Furthermore, Percentage of moisture in breast meat of birds in T1 $(75.59 \%)$ group was significantly higher $(\mathrm{P}<0.05)$ as compared to $\mathrm{T} 4 \quad(71.88 \%)$. However, there were no significant differences $(\mathrm{P}>0.05)$ between chicks fed on different DDGS levels in percentage of ash. 
Table 11: Effect of utilization (DDGS) as partial alternative of soybean meal on percentage of protein, lipid, moisture and ash in breast of broiler chicks performance. (Means $\pm \mathrm{SE}$ )

\begin{tabular}{|c|c|c|c|c|}
\hline \multirow{2}{*}{ Treatments } & \multicolumn{4}{|c|}{ Breast meat composition } \\
\hline & protein $(\%)$ & lipid (\%) & moisture $(\%)$ & $\operatorname{ash}(\%)$ \\
\hline $\mathrm{T} 1$ (control) & $21.17 \pm 0.35^{\mathrm{b}}$ & $2.18 \pm 0.41^{\mathrm{a}}$ & $75.59 \pm 0.48^{\mathrm{a}}$ & $1.06 \pm 0.00^{\mathrm{a}}$ \\
\hline $\mathrm{T} 2$ & $21.48 \pm 0.85^{\mathrm{ab}}$ & $1.90 \pm 0.54^{\mathrm{a}}$ & $75.48 \pm 1.10^{\mathrm{a}}$ & $1.14 \pm 0.04^{\mathrm{a}}$ \\
\hline $\mathrm{T} 3$ & $21.65 \pm 0.97^{\mathrm{ab}}$ & $2.52 \pm 0.21^{\mathrm{a}}$ & $74.62 \pm 0.86^{\mathrm{ab}}$ & $1.21 \pm 0.10^{\mathrm{a}}$ \\
\hline $\mathrm{T} 4$ & $23.93 \pm 0.76^{\mathrm{a}}$ & $2.78 \pm 0.33^{\mathrm{a}}$ & $71.88 \pm 0.89^{\mathrm{b}}$ & $1.42 \pm 0.20^{\mathrm{a}}$ \\
\hline
\end{tabular}

*: Means with different superscript within factor or factors combination differ significantly $(\mathrm{p}<0.05)$.

2.2 Estimation of the protein, lipid, moisture and ash in thigh meat

Percentages of protein, lipid, moisture and ash in thigh meat are presented in Table 12. DDGS levels had no significant effect on protein, lipid, moisture and ash percentage in thigh meat.

Table 12: Effect of utilization (DDGS) as partial alternative of soybean meal on percentage of protein, lipid, moisture and ash in thigh (FCR) of broiler chicks performance. (Means $\pm \mathrm{SE}$ )

\begin{tabular}{|c|c|c|c|c|}
\hline \multirow{2}{*}{ Treatments } & \multicolumn{4}{|c|}{ Thigh meat composition } \\
\hline & Protein $(\%)$ & lipid (\%) & moisture $(\%)$ & $\operatorname{ash}(\%)$ \\
\hline T1(control) & $21.68 \pm 0.39^{\mathrm{a}}$ & $6.55 \pm 0.14^{\mathrm{a}}$ & $70.71 \pm 0.27^{\mathrm{a}}$ & $1.06 \pm 0.12^{\mathrm{a}}$ \\
\hline $\mathrm{T} 2$ & $21.61 \pm 0.73^{\mathrm{a}}$ & $4.93 \pm 0.12^{\mathrm{b}}$ & $72.43 \pm 0.75^{\mathrm{a}}$ & $1.04 \pm 0.09^{\mathrm{a}}$ \\
\hline $\mathrm{T} 3$ & $22.15 \pm 0.77^{\mathrm{a}}$ & $5.61 \pm 0.73^{\mathrm{ab}}$ & $70.94 \pm 0.39^{\mathrm{a}}$ & $1.30 \pm 0.09^{\mathrm{a}}$ \\
\hline $\mathrm{T} 4$ & $22.89 \pm 0.64^{\mathrm{a}}$ & $5.13 \pm 0.27^{\mathrm{b}}$ & $70.66 \pm 0.38^{\mathrm{a}}$ & $1.32 \pm 0.06^{\mathrm{a}}$ \\
\hline
\end{tabular}

*: Means with different superscript within factor or factors combination differ significantly $(\mathrm{p}<0.05)$.

\section{DISCUSSION}

When comparing the content of nutrients in dried distillers grains with soluble applied in the experiment with results reported by Widyaratne \& Zijilstra (2007), we may state that they were characterised by a lower protein and ash content and simultaneously, contained more fat and crude fibre. Lysine content (lysine is the first limiting amino acid in feed containing dried distillers grains) and energetic value were also lower. It indicates the need for precise balancing of the formulations of feed mixtures with DDGS addition in respect of amino acid composition and metabolisable energy, and of their possible supplementation with synthetic amino acids.

The results of body weight in agreement with the results of Ghazalah et al. (2012) who found that the highest value of body weight was recorded by birds fed $40 \%$ DDGS replacement for soybean meal. On the contrary Batal and Dale (2003) in their results emphasize that level of $18 \%$ DDGS in feed mixtures for broilers adversely affected their final weight and feed conversion. Similar results Weight gain were also obtained by Ghazalah et al. (2012) who reported 
that the highest value of weight gain was recorded by birds fed $40 \%$ DDGS replacement for SBM. Whilst, results of the present study was disagreement with Wang et al. (2007b) who reported no significant effect of higher levels of DDGS in the diets for broilers on their performance. Some research results are similar with these results Foltyn et al. (2013) which mentioned significant positive effect of DDGS on weight of carcass. However, there were significant differences among the $\mathrm{T} 3$ and $\mathrm{T} 1$ in breast weight and also same results was recorded for thigh weight, In contrast to these results Min et al. (2008) reported that $30 \%$ DDGS levels caused a decrease in carcass yield in broilers. The wing weight of the T4 $(186.67 \mathrm{~g})$ compared to $\mathrm{T} 1(213.33 \mathrm{~g})$ was not different and decreased with increasing of DDGS levels. This result is not in agreement with the results of Wang et al. (2008) who found that 30\% DDGS levels caused a decline in carcass yield in broilers. Lumpkins et al. (2004) observed that feeding broiler chicks on diets containing $0,6,12$, or $18 \%$ DDGS had no effect on carcass yield. Wang et al. (2007a) and Wang et al. (2007b) found that there were no effects on carcass quality when they fed broilers on diets containing DDGS up to $15 \%$, also same researcher founds that there were no effects on carcass quality when they fed broilers on diets containing DDGS up to $15 \%$. (Schilling et al., 2010) Also describe no differences existed $(P>0.05)$ among thigh meat with respect to fat, protein, and moisture from broilers that were fed on various levels of DDGS. The recommended maximum dietary inclusion levels for corn DDGS are $15 \%$ for broilers, turkeys, layers, and ducks, but higher levels of corn DDGS can be used successfully with appropriate diet formulation adjustments for energy and amino acids. When formulating diets containing corn DDGS, digestible amino acid values should be used especially for lysine, methionine, cystine, and threonine. Diets should also be formulated by setting minimum acceptable levels for tryptophan and arginine due to the second limiting nature of these amino acids in corn DDGS protein.

\section{CONCLUSIONS}

According to the results, which are obtained under these conditions, it could be concluded that broiler chicks can tolerate different levels of DDGS up to $30 \%$ as replacement of soybean meal, with having positive effect on broiler performance. And also the DDGS had effect on carcass quality.

\section{REFERENCES}

Belyea, R.L.; Rausch, K.D. and Tumbleson, M.E. (2004): Composition of corn and distillers dried grains with solubles from dry grind ethanol procesing. Bioresources Technology, 94, 293-298.
Batal, A.B. and Dale, N.M. (2003): Mineral composition of distillers dried grains with solubles. J. App. Poult. Res. 12: 400-403.

Day, E.J.; Dilworth, B.C. and McNaughton, J. (1973): Unidentified growth factor sources in poultry diets. In "Proceedings Distillers Feed Research Council Conference". Pp.40-45. of Distillers Dried Grains plus Solubles in Broiler Diets. Poult Sci, 60: 1479-1484.

Duncan, D.B. (1955): Multiple ranges and multiple F- test. Biometrics, 11: 1-42.

Foltyn, Marian; Vojtěch Rada; Martina Lichovnikova and Eliška Dračkova, (2013): Effect of corn DDGS on broilers performance and meat quality, Acta Univeristatis Agriclturae et Silviculturae Mendelianae Brunensis, vol (1xe), 1, 59-64.

Ghazalah, A.A.; Abd-Elsamee, M.O.; Abd El-Hakim, A.S. and Ibrahim, M.M. (2012): Evaluation of using distillers dried grains with soluble (DDGS) in broiler diets. Poult. Sci., 32: 381397.

Leaflet, A.S. (2008): Maximum Dietary Content of Corn Dried Distiller's Grains with Soluble in Diets for Laying Hens. Effects on Nitrogen Balance, Manure Excretion, Egg production, and Egg Quality. Animal Industry Report 2008, Iowa State University, Available from: http://www.DDGS. umn.edu.

Lumpkins, B.; Batal, A.B. and Dale, N.M. (2004): Evaluation of distillers dried grain with solubles as a feed ingredient for broilers. Poult. Sci., 83: 1891-1896.

Min, Y.N.; Liu, F.Z.; Wang, Z.; Coto, C.; Cerrate, S.; Costa, F.P.; Yan, F. and Waldroup, P.W. (2008): Evaluation of distillers dried grains with solubles in combination with glycerin in broiler diets. International J. Poult. Sci. 7: 7, 646-654.

Nutrient Requirements of Poultry (NRC): Ninth Revised Edition, 1994, Subcommittee on Poultry Nutrition, National Research Council.

Renewable Fuel Association, RFA. (2005): Homegrown for homeland: Ethanol industryoutlook (2005). http://www. ethanolrfa.org/objects/pdf/outlook/outlook_20 05.pdf Accessed May 2005.

Schilling, M.W.; Battula, V.; Loar, R.E.; Jackson, V.; Kin, S. and Corzo, A. (2010): Dietary inclusion level effect of distillers dried grains with solubles on broiler meat quality. Poult Sci, 89: 752-760.

Waldroup, P.W.; Owen, J.A.; Ramsey, B.E. and Whelchel, D.L. (1981): The Use of High Levels Distillers Dried Grains plus Solubles in Broiler Diets. Poult Sci, 60: 1479-1484.

Wang, Z.; Cerrate, S.; Coto, C.; Yan, F. and Waldroup, P.W. (2007a): Use of constant or increasing levels of distillers dried grains with solubles (cDDGS) in broiler diets. 
International Journal Poultry Science. 6 (7): 501-507.

Wang, Z.; Cerrate, S.; Coto, C.; Yan, F. and Waldroup, P.W. (2007b): Utilization of Distillers Dried Grains with Soluble (DDGS) in Broiler Diets Using a Standardized Nutrient Matrix. International Journal of Poultry Science, 6 (7): 470-477.

Wang, Z.; Cerrate, S.; Coto, C.; Yan, F. and Waldroup, P.W. (2007c): Use of constant or increasing levels of distillers dried grains with solubles (DDGS) in broiler diets. International Journal Poultry Science. no. 6. p. 501-507.
Wang, Z.; Cerrate, S.; Coto, C.; Yan, F. and Waldroup, P.W. (2008): Evaluation of high levels of distillers dried grains with solubles (DDGS) in broiler diets. Int. J. Poult. Sci., 7 (10): 990-996.

Widyaratne, G. and Zijlstra, R. (2007): Nutritional value of and corn distiller's dried grain with soluble: Digestibility and digestible contents of energy, amino acids and phosphorus, nutrient excretion and growth performance of grower-finisher broilers. Can J. Anim. Sci. 87, 103-114

XISTAT. XLSTAT-Pro.User's Manual. Addinsoft, Paris, France, 230p. (2004).

\section{تاثير استخدام الـ (DDGS) في اداء فروج اللحم}

\section{سامان عبل المجيل رشبي ، هيرش عبل الازل فرج ، رووف حسبن فرج ، عطا محمد صالج ، كوربو اومبي حمة عزيز،

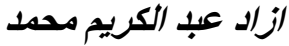

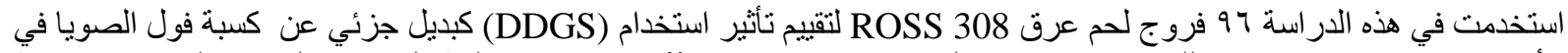

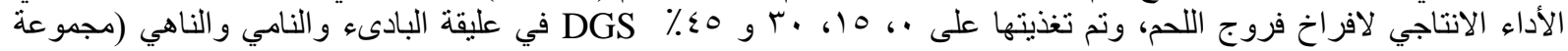

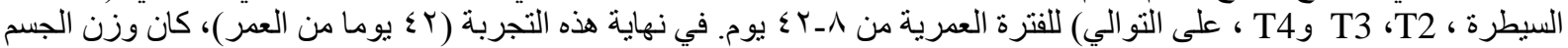

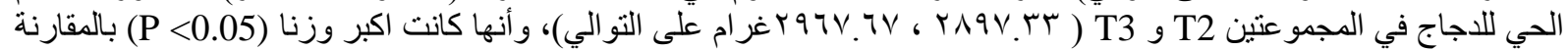

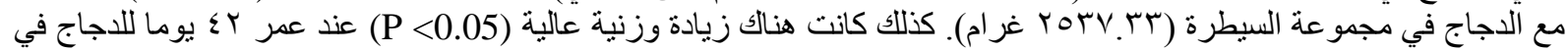

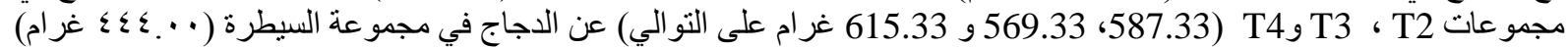

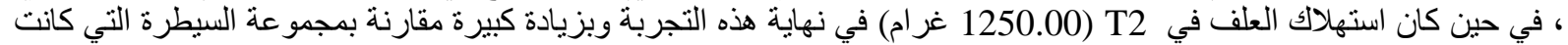

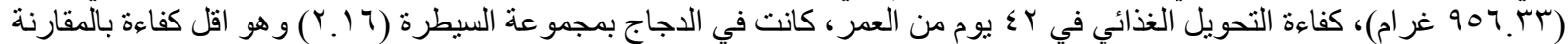

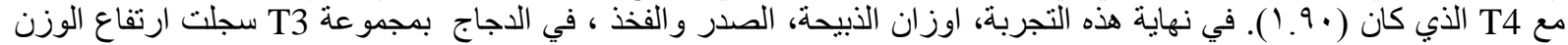

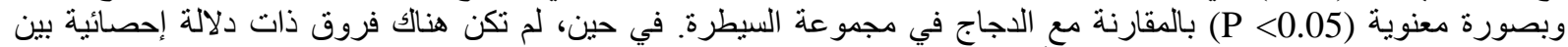

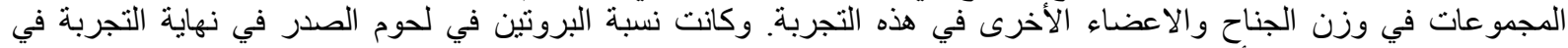

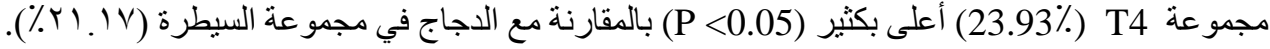

